\title{
Status of Information and Communication Technology Training and Support for Science and Technology Teacher Educators in Colleges of Education in Southeast, Nigeria
}

\author{
Ezenma Chimezie Bernard \\ University of Nigeria, Nigeria
}

\begin{abstract}
How to cite this paper: Ezenma Chimezie Bernard "Status of Information and Communication Technology Training and Support for Science and Technology Teacher Educators in Colleges of Education in Southeast, Nigeria" Published in International Journal of Trend in Scientific Research and Development (ijtsrd), ISSN: 24566470, Volume-3 | Issue-3 , April 2019, pp.939-946, URL: https://www.ijtsrd.c om/papers/ijtsrd21 511.pdf

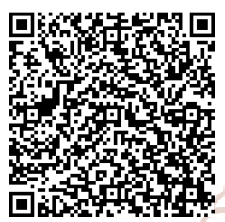

IITSRD21511

Copyright (C) 2019 by author(s) and International Journal of Trend in Scientific Research and Development Journal. This is an Open Access article distributed under the terms of the Creative Commons

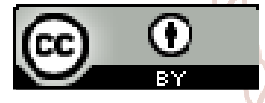
Attribution License (CC BY 4.0) (http://creativecommons.org/licenses/ by/4.0)
\end{abstract}

\section{INTRODUCTION}

Nigeria education policy makers and social planners, in recognitions of its potentials for integrating tertiary education into a global digital society, have emphasized the adoption of information and communication technology (ICT) by teachers in the tertiary institutions. This was made clear as the policy states that in recognition of the prominent role of ICT in advancing knowledge and skills necessary for effective functioning in the modern world, there is urgent need to integrate ICT into education in Nigeria (FRN, 2004). According to Daniels (2002) ICTs have become within a very short time, one of the basic building blocks of modern society. Many countries now regard understanding ICT and mastering the basic skills and concepts of ICT as part of the core of education.

\section{INFORMATION AND COMMUNICATION TECHNOLOGY}

The marriage of two technologies gave birth to the Information and Communication Technology. These technologies are the communication and the computer technology (Edward, 2007). The communication technology includes the radio, the television and the telephone technology, while the computer technology includes the computer, satellite, the wireless and the internet technology (Edward, 2007). ICT therefore, includes the radio, television and telephone, and the new'ICTs of computers, satellite and wireless technology and the internet (Potashnik and Copper, 2009). According to UNESCO (2002) information and communication technology (ICT) may be regarded as the combination of Informatics technology 'with other related technology, specifically communication technology. Information and communication technology (ICT) are advance in technologies that provide a rich global resources and collaborative environment for dissemination of ICT literacy, materials, interactive and educative discussions, and research information (Bates, 2011). ICT also enhances international exchange of ideas which are critical for advancing meaningful educational initiatives, training high skilled labour force, and understanding issues related to both education and economic development (Ololube, Ubogu and Ossai, 2011). Many tertiary institutions in Nigeria today are struggling to adopt the ICT as teaching and learning technologies. This is to be handled with skills and expertise for effective achievement and realization of its potential in both education and socio-economic development. 
Consequently, all people employed as teachers particularly science and technology teachers need to develop competence and skills in teaching.

Accordingly, the application of ICT makes institutions more efficient and productive, thereby engendering a variety of tools to enhance and facilitate teachers' pedagogical activities. ICT can also be used to promote collaborative learning, including role playing, group problem solving activities and articulated project (Fathi, Shelda and Nahid, 2010). The authors further opined that ICT is a diverse set of technological tools and resources used for creating, storing, managing and communicating information. For educational purposes, the ICTs can be used to support teaching and learning as well as research activities, including collaborative learning and inquiry. One of the main applications of ICT in education is teaching and learning based on new technologies. Therefore, Information and communication technology (ICT) involve the use of computer and all other electronic devices to process information. In concrete term, ICT enhances teaching and learning through its dynamic, interactive, flexible, and engaging content. It provides real opportunities for individualized instruction. ICTs have the potential to innovate, accelerate, enrich, and deepen skills, to motivate and engage students, to help relate school experience to work practices, create economic viability for tomorrow's workers, as well as strengthening teaching and helping schools change

\section{SCIENCE AND TECHNOLOGY TEACHER ICT TRAINING}

Teachers' training needs in Information and Communication Technologies (ICT) is one of the key aspects for the integration of ICT into daily educational practice, along with competencies in ICT and teachers' use of these technological resources (Almerich, Gonzalo, Belloch and Consuelo, 2011). ICT training is the process of learning ICT knowledge and skills needed to do job. ICT skill comprises training in the general understanding of the basic building blocks of the computer system, office application programs, sending email, making use of internet and so on. Specific ICT skills enable teacher to acquire ICT skills in order to enhance the quality of teaching and learning that takes place in the institutions. It involves training on how to use computer in subject-based teaching, power point presentation of lesson using multimedia, computer assisted instruction (CAI) software packages, statistical package for science and social science (SPSS), curriculum design/redesign of new learning activities, developing digital material and developing vision of IT in education. According to Jegede (2009) the purpose of these training and support is making teacher educators ICT skilled both in personal activities and day- to- day professional practice. The problem has been that these trainings do not impact the integration of ICT into teacher educators classroom especially science and technology teacher educators' classroom. At best, science and technology teacher educators use the internet and in few cases use computer for word processing. Thus, teaching with ICT in colleges of education still becomes impossible to achieve. Jegede (2009) also maintains that this is because serving teachers (science and technology teachers inclusive) did not experience ICT immersed curriculum in their professional preparations and they pass on what they receive. ICT in education (2004) opines that, the most critical factor in the successful integration of ICT into education is the extent to which teacher educators are able to prepare teachers with the required knowledge and skills to utilize ICT effectively. Oliver in Jegede (2009) identified the needs for student teacher to experience models of ICT used in their own learning before they can go ahead to implement same in their later profession. UNESCO (2002) clearly pointed out that teachers education institutions (colleges of education institutions inclusive) may either assume a leadership role in the transformation of education or be left behind in the swirl of rapid technological changes. Bada et el. (2009), investigated the uses of computer and its relevance to teaching and learning in Nigeria education system. In more recent work, Inyiagu (2014) investigated the utilization of internet and computer in undertaking TVET educational research in tertiary institutions in Nigeria: Problems and Strategies for improvement. However, having reviewed related topics, it will be imperative to identify the reasons why most college of education students prefer to source for information from internet facilities outside their school. Therefore, this research work examined the status of information and communication technology training and support for science and technology teacher educators in colleges of education within Southeast Nigeria.

\section{SCIENCE AND TECHNOLOGY TEACHER ICT SUPPORT}

ICT support for teacher educators refers to incentives aimed at helping or encouraging teacher educators in learning/ acquiring ICT knowledge and skills in order to use skills and produce ICT competent teachers. Studies carried out on ICT training and support indicates that teachers in colleges of education do not use ICT for instructional delivery and need training and support in this and in the development of ICT Programmes (Nwagbo, 2008). This is in line with Benton foundation (1997), who maintained that inadequate ICT training and supports are perhaps the biggest bottleneck limiting effective use of computer networking in many of the nation's classroom.

Apart from the introduction of ICT into the education domain, the last decade has witnessed the development of teacher training programmes for both teacher training and professional development purposes. Despite pursuing the same aim, that of integrating ICT into daily practices, the differences between both groups imply required training diversity (Condie and Munro, 2007; Ertmer and OttenbreitLeftwich, 2010), but without leaving to one side the required continuity between initial training and continuous training, as Marcelo (2007) pointed out. This, therefore calls for the acute need to avail teachers the opportunity of learning to use multimedia in instructional delivery. Should the teachers who are supposedly the master of knowledge fail to change with the dictates of globalization and buries themselves in their textbook, old research topics while the world is on the superhighway of information, the science and technology teacher educators would not be competent to teach the children of $21^{\text {st }}$ century. For science and technology teacher educators to be seen as learners themselves, we need to build bridge between different area of research in education, learning theories, ICT and management to mention but the four.

ICT training and support for science and technology teacher educators in southeast Nigeria states are not without some challenges. There is therefore, need to investigate some of the factors militating against ICT training and support for science and technology teacher educators such as lack of fund, high cost of computer hardware etc. 


\section{STATEMENT OF THE PROBLEM}

Nigeria must brace up to the new challenges and system of education through deployment and use of ICT in science and technology instructions. However, studies have shown that Nigeria teacher educators can neither use the computer efficiently nor develop ICT programme or package for instructional or other uses. Also pre- service science and technology teachers for the primary and secondary level of education have been found to posses' low competence in the use of computers and are not equipped with relevant ICT skills, in the use of ICT applications in teaching. Weak policy formulation and implementation, high cost of system installation and maintenance, poor founding of education, management's attitude, and erratic power supply etc are major constraints which have slowed down ICT in Nigeria.

Therefore, there is need to empirically determine the extents of preparedness of science and technology teacher educators in the colleges of education to impact ICT knowledge and skills to the pre-service science and technology teacher educators. The problem therefore is, what is the status of ICT training and support for science and technology teacher educators in colleges of education in Southeast Nigeria? Would ownership and location of colleges of education affect ICT training and support for science technology teacher educators?

\section{RESEARCH QUESTIONS}

In carrying out this study, seven research questions were posed to guide in investigations. They are:-

1. What is the level of ICT training received by science and technology teacher educators in colleges of education within Southeast Nigeria?

2. What is the kind of ICT support received by science and technology teacher educators in colleges of educations within Southeast Nigeria?

3. What is the level of competence attained by science and technology teacher educators in colleges of education within Southeast Nigeria?

4. To what extent do science and technology teacher educators utilize ICT knowledge acquired in colleges of education within Southeast Nigeria?

5. To what extent do science and technology teacher educators rate different factors as militate against effective ICT training and support in colleges of education within Southeast Nigeria?

\section{RESEARCH HYPOTHESES}

Five null research hypotheses were posed for the study, and were tested at 0.05 level of significant. They are as follows:

$\mathrm{H}_{01}$ There is no significant difference in the level of ICT training received by science and technology teacher educators in colleges of education within Southeast Nigeria due to location.

$\mathrm{H}_{02}$ There is no significant difference in the kind of support received by science and technology teacher educators in colleges of educations within Enugu state due to location.

$\mathrm{H}_{03}$ There is no significant difference in the level of ICT competence attained by science and technology teacher educators in colleges of education within Southeast Nigeria due to location.

$\mathrm{H}_{04}$ There is no significant difference in the extent of utilization of ICT knowledge acquired by science and technology teacher educators within Southeast Nigeria due to location.
$\mathrm{H}_{05}$ There is no significant difference on the extent science and technology teacher educators' rates' different factors as militating against effective ICT training and support in colleges of education in Southeast Nigeria due to location.

\section{METHODOLOGY}

\section{Research Design}

The design of the study is a descriptive survey. According to Nwakwo (2013), descriptive survey is that type of design in which the researcher collects data from a large sample drawn from a given population and describes certain features of the samples as they are at the time of the study and which are of interest to the researcher, however, without manipulating any independent variables of the study. It is also a data collection technique in which information is gathered from individual called respondents, by having them respond to questions. The reason for using a survey research design was that questionnaire was used to collect data concerning existing condition.

\section{Area of the Study}

The study was conducted in Southeast Nigeria. Southeast Nigeria is made up of five states namely- Enugu, Anambra, Ebonyi, Imo, and Abia state. The study was conducted in colleges of education in Southeast Nigeria covering federal, state and private colleges of education: Federal College of Education, Eha-Amufu, Federal College of Education, Umunze Anambra state, Alvan Ikoku College of Education Owerri, Our Saviour Institute of Science and Technology Enugu, Institute of Ecumenical Education, (Thinkers Corner), Enugu, African Thinkers Community of Inquiry College of Education Enugu, Havard Wilson College of Education Abia, Enugu State College of Education (Technical), Enugu State, Imo State College of Education, Ihitte Uboma, College of Education, Arochukwu, Abia, Peaceland College of Education, Enugu, and The College of Education, Nsukka. Southeast Nigeria was chosen for this study because it has colleges of education where science and technology education programmes are offered.

\section{Population for the Study}

The population of the study consisted of all the science and technology teacher educators in twelve (12) colleges of education within Southeast Nigeria. The population of the study cut across one (3) Federal college of education, one (3) State colleges of education and five (6) private colleges of education located within the states. The total population of science and technology teacher educators in colleges of education Southeast Nigeria is four hundred and fifty four (454) (NCCE statistics digest, 2018) with the distribution as follows - Federal college of education Eha-Amufu, Enugu State (48), Federal College of Education, Umunze Anambra state (42), Alvan Ikoku College of Education Owerri (54), Enugu state college of education technical (75), Imo State College of Education, Ihitte Uboma (71), College of Education, Arochukwu, Abia (52), Havard Wilson College of Education Abia(12), African Thinkers' community of inquiring college of Education Enugu (23), Peace Land college of Education Enugu state (19), Our Saviour Institute of Science and Technology Enugu (20), Institute of Ecumenical Education, (Thinkers Corner), Enugu (25), and The College of Education, Nsukka (13). The choice for including private colleges of education was to ensure even representation of all government approved colleges of 
education in the area of study. There was no sampling due to the manageable size of the population size by the researcher.

\section{Instrument for Data Collection}

The instrument used for data collection was structured questionnaire. The questionnaire comprised of six sections. The kinds or sources of ICT support received, the level of ICT training and support received, the science and technology teacher educators' level of ICT competence attained, the science and technology teacher educators extent of utilization of ICT knowledge in teaching and learning and the factors militating against effective ICT training and support.

The level of ICT support received by science and technology teacher educator consisted of eleven (11) questionnaire items developed by the researcher using four points rating scale: Strongly Agreed (4) Agreed (3) Disagreed (2) and Strongly Disagreed.

The level of training received by science and technology teacher educators consisted of 22 questionnaires items developed by the researcher using four point rating scale: very high level (4), High level (3), Low level (2), and very low level (1). The reason for using four point rating scale was that nominal values were used to assign scaling items. The kind of ICT support received by science and technology teacher educators also consisted of 11 questionnaires items, with question number one to five originally developed by Nwagbo and Okoli (2008) in their study and the test were designed by the researcher. Respondents indicated their response by ticking against the kind of support they have received. The level of ICT competence attained by science and technology teacher educators consisted of 18 questionnaires items, developed by the researcher. The items covered internet skills, teaching with ICT, Basic computer skills, data processing skills and skills for application packages. Respondents indicated their ICT competence on a 4-point scale of very high competence level (4), high competence level (3), low competence level (2), and very low competence level (1).

The extent of ICT utilization by science and technology teacher educators consisted of 13 questionnaires items. Respondents indicated their extent of utilization of ICT knowledge in teaching and learning on a 4-point rating scale of very high extent (4), high extent (3), low extent (2), and very low extent (1).

Finally the factors militating against effective ICT training and support consisted of 15 questionnaires items developed by the researcher. The items covered the possible factors that militate against effective ICT training and support for science and technology teacher educators. Respondents indicated their response on a 4-point rating scale of strongly Agreed (4), Agreed (3), Disagreed (2), Strongly Disagreed (1).

\section{Validation of the Instrument}

The instrument were face validated by three experts, three draft copies of the instrument were given to three expert; two from the department of science and computer education, Enugu state University of science and technology, Enugu, and one from the department of computer and robotic education, University of Nigeria, Nsukka. After validation, the instruments were collected from the valuators and corrections made.

\section{Reliability of the Instrument}

The instrument was trail tested to determine its reliability by using 10 science and technology teacher educators from Yaba College of Education Technology Lagos. Ten copies of questionnaire were administered by the researcher to the respondents. When completed, was immediately collected by the researcher. Responses obtained from the administered questionnaire were calculated using Cronbach's Alpha coefficient. The data generated were used to calculate the alpha coefficient yielded reliability co-efficient of 0.98 . According to Lobiondo and Haberan, (2013); Shuttleworth (2015) an acceptable reliability score is one that is 0.7 and higher. The result 0.98 is good because it is more than 0.8 . The reason for using Cronbach's alpha was that, the instrument used for data collection was polychotomous.

\section{Method of Data Analysis}

Data collected were presented in tables and analyzed using mean standard deviation, and one way ANOVA. Research question 1, 2, 3,4,5,6 and 7 were analyzed using mean and standard deviation. Nominal values assigned to scaling items i.e. very high extent (4), extent (3), low extent (2), and very low extent (1) were used to determine the mean. This gives:

$$
4+3+2+1 / 4=10 / 4=2.5
$$

The decision rule was that, mean scores of 2.5 and above were regarded as high while item with mean score below 2.5 were regarded as low. Testing of the null hypotheses was done using one-way ANOVA. At 0.05 alpha level of significant. Hypotheses 1, 2, 3, 4,5,6,7,8,9,10,11 and 12 were tested using one way ANOVA. The decision rule for the null and direct hypotheses was that, if the calculated value is less than the critical table value for the given degree of freedom, the null hypotheses is upheld, but, if the calculated value is greater than the critical value, the null hypotheses is rejected.

\section{RESULTS}

\section{Research question 1}

What is the extent of ICT training received by science and technology teacher educators in colleges of education in Southeast Nigeria?

Table 1: Mean and standard Deviation of respondents on the level of ICT training received. Total Population: 454 science and technology teacher educators.

\begin{tabular}{|c|c|c|c|c|}
\hline Item no & Item & MEAN & SD & REMARK \\
\hline 12 & Computer appreciation & 2.91 & 0.52 & high level \\
\hline 13 & Word processing & 2.95 & 0.66 & high level \\
\hline 14 & Information retrieval using CD-ROM, flash and others. & 2.46 & 0.30 & Low level \\
\hline 15 & Simple desktop publishing & 2.2 & 0.16 & Low level \\
\hline 16 & Graphic and art work & 2.3 & 0.44 & Low level \\
\hline 17 & Drill and practice activities & 2.39 & 0.52 & Low level \\
\hline
\end{tabular}


International Journal of Trend in Scientific Research and Development (IJTSRD) @ www.ijtsrd.com eISSN: 2456-6470

\begin{tabular}{|l|c|c|c|c|}
\hline 18 & Use of multimedia presentation & 2.23 & 0.28 & Low level \\
\hline 19 & Use of interactive software & 2.4 & 0.39 & Low level \\
\hline 20 & Use of internet facilities & 2.41 & 0.49 & Low level \\
\hline 21 & Overall development in communication and information technology & 2.46 & 0.33 & Low level \\
\hline 22 & Power point presentation & 2.41 & 0.29 & Low level \\
\hline 23 & Use of computer assisted instruction & 2.38 & 0.28 & Low level \\
\hline 24 & Use of computer to generate lesson plan & 2.42 & 0.28 & Low level \\
\hline 25 & Use of ICT for cooperative learning and for peer interaction & 2.4 & 0.34 & Low level \\
\hline 26 & Use of ICT for keeping students record & 2.39 & 0.38 & Low level \\
\hline 27 & Evaluating technology based learning & 2.41 & 0.34 & Low level \\
\hline 28 & Use of SPSS package & 0.20 & Low level \\
\hline 29 & Use of networking package & 2.18 & 0.16 & Low level \\
\hline 30 & Use of computer to evaluate students learning & 2.35 & 0.30 & Low level \\
\hline 31 & Evaluating students learning from computer based activities & 2.1 & 0.21 & Low level \\
\hline 32 & Using of spreadsheet package & 3.17 & 0.76 & High level \\
\hline 33 & Use of Microsoft access & 0.83 & High level \\
\hline
\end{tabular}

The data presented in table 1 above indicates that out of twenty two (22) items on ICT training received by the respondents, only four (4) items, obtained mean score rating above 2.5. These include, item 12 (2.91), item 13 (2.95), item 32(3.17), and item 33 (3.1). Others obtained mean rating below 2.5 as seen in the table. The standard deviation of the items ranged from 0.53 to 0.83. The result presented in table 1 indicates that respondents received more ICT training in computer appreciation, word processing, spreadsheet package and Microsoft access package with mean ratings of 2.91, 2.95, 3.17 and 3.1 respectively. This was closely followed by information retrieval using CD-ROM with mean rating of 2.46

\section{Research question 2}

What is the kind of ICT support received by science and technology teacher educators in colleges of education in Southeast Nigeria?

Table 2: Mean and standard deviation of respondents on the kind of ICT support received.

Total Population: 454 science and technology teacher educators.

\begin{tabular}{|c|l|c|c|c|}
\hline Item no & \multicolumn{1}{|c|}{ Item } & \multicolumn{1}{|c|}{ Mean } & SD & \multicolumn{1}{|c|}{ Remark } \\
\hline 1 & possess computer in office & 3.19 & 0.79 & High support \\
\hline 2 & Computer provided by employer.velopment & 2.41 & 0.44 & Low support \\
\hline 3 & Projector provided by employer. & 2.48 & 0.33 & Low support \\
\hline 4 & $\begin{array}{l}\text { Attended workshop/seminar/conference for ICT } \\
\text { pedagogical renewal in the last two years. }\end{array}$ & 2.65 & 0.45 & High support \\
\hline 5 & Workshops were sponsored by employer. & 2.65 & 0.38 & High support \\
\hline 6 & $\begin{array}{l}\text { Seminars were sponsored by National/international } \\
\text { agency. }\end{array}$ & 2.65 & 0.49 & High support \\
\hline 7 & Conferences were sponsored by self. & 2.55 & 0.34 & High support \\
\hline 8 & Internet facilities in the school provided by employer. & 2.44 & 0.51 & Low support \\
\hline 9 & Received research grant on ICT to enhance your teaching. & 2.64 & 0.38 & High support \\
\hline 10 & $\begin{array}{l}\text { Multimedia for instruction provided for you in the } \\
\text { classroom. }\end{array}$ & 2.1 & 0.15 & Low support \\
\hline 11 & $\begin{array}{l}\text { Received special allowance as science and technology } \\
\text { teacher Educators to enhance ICT competence level. }\end{array}$ & 2.24 & 0.21 & Low support \\
\hline
\end{tabular}

Table 2 above shows that out of 11 items on the kind of ICT support received by the respondents, six (6) items obtained mean score rating above 2.5. These include item 1 (3.18), item 4 (2.65), item 5 (2.65), item 6 (2.65), item 7 (2.55), and item 9 (2.63). Others obtained mean score rating bellow 2.5 as seen in the table. The standard deviation of the six items ranges from 0.38 to 0.78. The table indicates that respondents received more ICT support in computer provided in office, computer provided by employer, attended workshop/seminar/conference for ICT pedagogical renewal in the last two years, workshop were sponsored by employer, seminar were sponsored by National/international agency, conferences were sponsored by self, received research grant o ICT to enhance your teaching. With mean rating score of $3.18,2.65,2.65,2.65,2.55$, and 2.63 respectively.

\section{Research question 3}

What is the level of ICT competence attained by science and technology teacher educators in colleges of education within Southeast Nigeria? 
International Journal of Trend in Scientific Research and Development (IJTSRD) @ www.ijtsrd.com eISSN: 2456-6470

Table 3: Mean and standard deviation of respondents on the level of ICT competence attained by science and technology teacher educators in colleges of education within Enugu state of Nigeria.

Total Population: 454 science and technology teacher educators.

\begin{tabular}{|c|c|c|c|c|}
\hline Item No & Item & MEAN & $\overline{\text { SD }}$ & REMARK \\
\hline 34 & $\begin{array}{l}\text { An understanding of the functions of the various components of } \\
\text { computer }\end{array}$ & 3.1 & 0.83 & high competence \\
\hline 35 & Use of Variety of software including, word processing functions & 3.2 & 0.78 & High competence \\
\hline 36 & Information retrieval through the use of CD-ROM & 2.40 & 0.45 & Low competence \\
\hline 37 & Preparation of graphics and artworks & 2.44 & 0.44 & Low competence \\
\hline 38 & Simple desktop publishing & 2.37 & 0.51 & Low competence \\
\hline 39 & Drill and practice activities & 2.37 & 0.31 & Low competence \\
\hline 40 & Using multimedia presentation & 2.36 & 0.35 & Low competence \\
\hline 41 & Using interactive presentation & 2.43 & 0.34 & Low competence \\
\hline 42 & The ability to use the internet & 2.36 & 0.36 & Low competence \\
\hline 43 & $\begin{array}{l}\text { Awareness of overall developments in communication and } \\
\text { information technology for students learning. }\end{array}$ & 2.31 & 0.41 & Low competence \\
\hline 44 & Power point presentation & 2.65 & 0.40 & High competence \\
\hline 45 & Use of computer assisted instruction (CAI) software & 2.43 & 0.31 & Low competence \\
\hline 46 & Use of Variety of software, including SPSS and AutoCAD & 2.3 & 0.30 & Low competence \\
\hline 47 & Use of spreadsheet functions & 2.2 & 0.29 & Low competence \\
\hline 48 & Use of Microsoft access functions & 3.13 & 0.68 & High competence \\
\hline 49 & $\begin{array}{l}\text { Knowledge of Area networking including area local network and wide } \\
\text { area network }\end{array}$ & 2.95 & 0.7 & High competence \\
\hline 50 & Ability to use electronic mail & 2.25 & 0.28 & Low competence \\
\hline 51 & 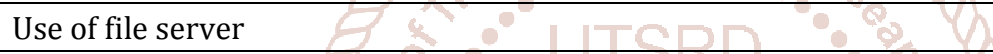 & 2.63 & 0.50 & High competence \\
\hline
\end{tabular}

The data presented in table 3 above indicates that out of eighteen (18) items only five (5) items obtained mean score rating above 2.5. These include item 34 (3.1), item 35 (3.2), item 44 (2.65), item 48 (3.14), and item 51 (2.62). Others obtained mean score rating bellow 2.5 as seen in table 3 above. The standard deviation for the five items ranges from 0.40 to 0.83 . Result shows that respondents possess more ICT competence in the functions of the various components of computer, use of variety of software, including word processing functions, power point presentation, and use of Microsoft access functions, use of file server with mean score rating of $3.1,3.2,2.65,3.14$, and 2.62 respectively.

\section{Research question 4}

To what extent do science and technology teacher educators utilize ICT knowledge acquired in colleges of education within Southeast Nigeria?

Table 4: Mean and standard deviation of respondents on extent of utilization of ICT knowledge acquired. Total Population: 454 science and technology teacher educators.

\begin{tabular}{|c|l|c|c|c|}
\hline Item No & \multicolumn{1}{|c|}{ Item } & MEAN & SD & REMARK \\
\hline 52 & Using computer to generate lesson plan & 2.32 & 0.32 & Low extent \\
\hline 53 & Evaluating computer software for teaching and learning & 2.11 & 0.26 & Low extent \\
\hline 54 & $\begin{array}{l}\text { Structuring subject programmes and lessons to incorporate useful and } \\
\text { appropriate computer and other ICT activities }\end{array}$ & 2.31 & 0.41 & Low extent \\
\hline 55 & Evaluating students' learning from computer based activities & 2.16 & 0.42 & Low extent \\
\hline 56 & The ability to select and evaluate technology based learning & 1.94 & 0.24 & Low extent \\
\hline 57 & Using ICT for record keeping and other relevant data/information for students & 2.4 & 0.39 & Low extent \\
\hline 58 & Selecting and evaluating technology based learning activities & 2.25 & 0.35 & Low extent \\
\hline 59 & Using ICT for co-operative learning and for peer interaction & 2.42 & 0.37 & Low extent \\
\hline 60 & $\begin{array}{l}\text { Using ICT to assist in organization and structuring of new courses and course } \\
\text { materials }\end{array}$ & 2.34 & 0.35 & Low extent \\
\hline 61 & Using ICT for time-table schedule & 2.35 & 0.45 & Low extent \\
\hline 62 & Using multimedia presentation in the classroom & 2.1 & 0.37 & Low extent \\
\hline 63 & Using computer- assisted instruction package & 2.375 & 0.31 & Low extent \\
\hline 64 & Use of ICT for research & 3.06 & 0.66 & High extent \\
\hline
\end{tabular}

The table 4 above indicates that out of the thirteen (13) items; only one (1) item was up to the mean rating of 2.5. The standard deviation for item sixty four (64) is 0.66 with mean score rating of 3.06 . The rest of the item obtained mean score rating that is bellow 2.5 
The result presented in the table shows that the extent of utilization of information and communication technology knowledge acquired by the respondents is very low.

\section{Research question 5}

To what extent do science and technology teacher educators rate different factors as militate against effective ICT training and support in colleges of education within Southeast Nigeria?

Table 5: Mean and standard deviation of respondents on different factors as militate against effective IC Training and support.

Total Population: 454 science and technology teacher educators.

\begin{tabular}{|c|l|c|c|c|}
\hline Item No & \multicolumn{1}{|c|}{ Item } & MEAN & SD & REMARK \\
\hline 65 & Lack of fund & 3.13 & 0.85 & High extent \\
\hline 66 & Low level of internet connectivity & 2.88 & 0.5 & High extent \\
\hline 67 & Management's attitude & 2.75 & 0.51 & High extent \\
\hline 68 & High cost of ICT resources & 2.68 & 0.44 & High extent \\
\hline 69 & Insufficient computer facilities & 2.94 & 0.5 & High extent \\
\hline 70 & Inadequate ICT infrastructural facilities & 2.75 & 0.54 & High extent \\
\hline 71 & Irregular power supply & 3.05 & 0.66 & High extent \\
\hline 72 & Lack of coherent instructional plan for ICT & 2.57 & 0.41 & High extent \\
\hline 73 & Inadequate curriculum & 2.55 & 0.32 & High extent \\
\hline 74 & Problem about accessibility of existing hardware & 2.51 & 0.35 & High extent \\
\hline 75 & Scarcity of resources & 2.66 & 0.40 & High extent \\
\hline 76 & Lack of interest of teachers in ICT usage & 2.65 & 0.47 & High extent \\
\hline 77 & Insufficient number of media (printer, scanner) & 2.7 & 0.41 & High extent \\
\hline 78 & Deficiency in support services in material development and ICT usage & 2.55 & 0.47 & High extent \\
\hline 79 & lack of computer laboratory & 2.62 & 0.37 & High extent \\
\hline 76 & Lack of interest of teachers in ICT usage & 2.65 & 0.47 & High extent \\
\hline 77 & Insufficient number of media (printer, scanner) & 2.7 & 0.41 & High extent \\
\hline 78 & Deficiency in support services in material development and ICT usage & 2.55 & 0.47 & High extent \\
\hline 79 & lack of computer laboratory & 2.62 & 0.37 & High extent \\
\hline
\end{tabular}

The table above shows that in all the items, none of the items indicated a mean rating score bellow 2.5. This therefore means the all the items obtained a mean rating score above 2.5 on different factors militating against effective ICT training and support. The mean rating score ranges from 2.55 to 3.13 and the standard deviation ranges from 0.34 to 0.85 . The results presented in the table indicate that all the factors militating against effective ICT training and support as indicated by the respondent is very high.

\section{Summary of Findings}

The results presented reveals the following:

1. ICT training among the respondents is very low. Although ICT training is going on gradually, the respondents received training mainly in computer appreciation, word processing, spreadsheet package and Microsoft Access. Also the interaction effect of urban and rural colleges of education is not significant.

2. ICT support among the respondents is slightly high. For instance, respondents indicated high possession of computer in the office. It also reveals that educators in colleges of education attended workshop/seminar/conference for ICT pedagogical renewal in the last two years, workshop were sponsored by employer, seminar sponsored by national agency, conferences were sponsored by self, internet facilities in the school provided by employer were high.

3. There is low ICT competence among the respondents. Also there is no significant difference based on the competence level of the respondents due to location.

4. The extent of ICT utilization of ICT knowledge acquired by the respondents is very low. The null hypotheses analysis shows that there is no significant difference on the extent of ICT utilization among the respondents due to location.

5. The respondents rated all the factors in table 5 (see table 5) as militating against effective ICT training and support. It also shows that there is no significant difference on the factors militating against ICT training and support due to location.

\section{Conclusions based on the findings}

Based on the findings of the study, the following were drawn: that ICT training and support among science and technology teacher educators in colleges of education in Southeast Nigeria is very low. Although training has been going on gradually, more effort should be geared towards ICT training for science and technology teacher educators in colleges of education within Southeast Nigeria. This will enable them attain the desired ICT competence needed in the classroom.

ICT support is also slightly low for science and technology teacher educators in colleges of education in Enugu state. Generally, federal college of education is rated higher in ICT training, support and competence than their counterparts.

There is equally low ICT competence and poor utilization of ICT knowledge acquired by science and technology teacher educators in colleges of education within Southeast Nigeria. Finally, many factors such as lack of fund, low level of internet connectivity, unreliable power supply, management attitude to mention but the four are some of the numerous factors that militate against ICT training and support for science and technology teacher educators in colleges of education within Southeast Nigeria.

\section{Recommendations}

Based on the findings made and conclusions drawn from the study, the following recommendations were made.

1. Government should provide support services to teacher educators of science and technology in colleges of education to enhance their knowledge in ICT 
2. Government should organize and sponsored ICT seminar, workshop and conference on ICT pedagogical innovation for science and technology teacher educators.

3. Administrators and managements of private colleges of education both in urban and rural area should be of help in founding, training and retraining of their staff

4. Government should ensure restructuring, development and reinforcement of the Nigeria policy for integration of ICT in the Nigeria education system.

\section{ACKNOWLEDGEMENTS}

Special gratitude goes to the Management of the University of Nigeria Nsukka. The researchers appreciate the effort of lectures that helped for the success of this study and all the research assistants.

\section{REFERENCES}

[1] Akudolu, L.R. (2002). Information and communication technology (ICT centered Education. A necessity for national development. Nigeria Journal of Computer literacy (N.J.C.L.), 3 (1), 8-10.

[2] Almerich, Gonzalo, Belloch, Consuelo. (2011). Training Needs of Teachers in ICT : Training Profiles and Elements of Complexity. e-Journal of Educational Research, Assessment and Evaluation v. 17, n. 2, art.1. https://www.researchgate.net/publication/25908212 5 .

[3] Bates, A. (2011). The continuing evolution of ICT capacity: Implications for education \| in G.M Farrell (ed.). The changing faces of virtual education. http://ww.col.org/nirtualed/virtual12pdfs. retrieved 18th Sept. 2013.

[4] Edward, N (2007). Development and Integration of Web-based technology in distance education for nurses in China: A pilot study. http://www.clerc.org/edwardsn. Retrieved 15th August, 2013.

[5] Condie, R. and Munro, B. (2007). The impact of ICT in schools- a landscape review. Becta research. London: Becta Retrieved from http://webarchive.nationalarchives.gov.uk/ 20101102103654/http://publications.becta. org.uk/download.cfm?resID=28221.

[6] Daniels J.S. (2002) -"Foreword" in Information and Communication Technology in Education-A Curriculum for Schools and Programme for Teacher Development. Paris: UNESCO.

[7] Ertmer, P. A. and Ottenbreit-Leftwich, A.T. (2010). Teacher Tecnology Change; How Knowledge, Confidence, Beliefs and Culture Intersect. Journal of Research on Technology in Education, 42(3), 255-284.

[8] ICT in Education (2004). Information and communication technology in teacher Education: A planning guide. Available at http//www.unescobkk.org/indexpdf?id=3806.

[9] Fathi, C., Shelda, A. \& Nahid, W. (2010). Education and technology revolution, ending the cycle of failure, teaching and technology group (online.) http://www.tctgroup.org/resources. Retrieved 10th August, 2013.
[10] Inyiagu, E.E. (2014). Utilization of Internet and Computer in Undertaking TVET Educational Research in Tertiary Instittutions in Nigeria: Problems and Strategies for Improvement. A journal presented at the 1st International Conference and 27th Annual General Meeting Akoka 2014 . Pp 18-21.

[11] Jegede, P. O. (2009). Assessment of Nigeria teacher educators' ICT Training. An online journal of issue in information science and Information technology, 14542.

[12] Lobiondo-Wood G, Haber J. (2013). Nursing research in Canada.Methods, critical appraisal, and utilization. 3rd Canadian edn.Toronto: Elsevier, 2013.

[13] Marcelo, C. (2007). La formación docente en la sociedad del conocimiento y la información: avances y temas pendientes. Olhar de professor, 10(1), 63-90.

[14] Nwakwo, O.C. (2013). A Practical Guide to Research Writing for students of research enterprise (Revised fifth edition). Port-Harcourt: University of Port--Harcourt press. 0794-1412. VOL1 NO5. Pp 65-77

[15] Nwagbo,E.E. (1998). Rural development as basis for science and technology Curriculum development. Journal of education for national development And international co-operation. Published by Nigeria association of Educationist for national Development (NAEND) 2(1), 49-53.

[16] Ololube, N. P., Ubogu, A.E. \& Ossai, A.G. (2011). ICT and distance education in Nigeria: A review of literature and account, 2nd international Open and Distance Learning (IODL) symposium.

[17] Potashinik, M. \& Copper, J. (2009). Distance Education: Growth and diversity. http://www.worlfbank.org/fandd/english/pdfs/0398. Retrieved 14th August 2013.

[18] Sanyal, B. C. (2001), 'New functions of higher education and ICT to achieve education for all', Paper prepared for the Expert Roundtable on University and Technologyfor-Literacy and Education Partnership in Developing Countries, International Institute for Educational Planning, UNESCO, September 10 to 12, Paris.

[19] Syed Noor ul Amin (2013) An effective use of ICT for education and learning by drawing on worldwide knowledge, research and experience: ICT as a change agent for education (A Literature review). Scholarly Journal of Education Vol. 2(4), pp. 38-45, April 2013 Available online at http:// www.scholarlyjournals.com/SJE ISSN 2315-6155 (C) 2013 ScholarlyJournals.

[20] UNESCO (2002) Information and Communication Technology in Education-A Curriculum for Schools and Programme for Teacher Development. Paris: UNESCO.

[21] UNESCO (2002). Information and communication technology in teacher Education: A planning Guild. http://www.unesco.org. Vygotsky, R. (1978). Mind in society: The development of higher psychological Processes. Cambridge, M.A., Harvard University press.

[22] UNESCO (2002).Open And Distance Learning Trends, Policy and Strategy Considerations', 14 UNESCO. 